\title{
Some Theoretical Observations on Discourse (and Text)
}

\author{
Jelena Jovanović Simić, Radoje Simić \\ Department of Serbian Language, Faculty of Philology, University of Belgrade, Belgrade, Serbia
}

Email address:

jelenajo@bitsyu.net (J. J. Simić)

\section{To cite this article:}

Jelena Jovanović Simić, Radoje Simić. Some Theoretical Observations on Discourse (and Text). International Journal of Language and Linguistics. Vol. 7, No. 1, 2019, pp. 8-12. doi: 10.11648/j.ij11.20190701.12

Received: December 3, 2018; Accepted: December 29, 2018; Published: January 24, 2019

\begin{abstract}
In the proposed study, the authors deal with a discourse (compared to a text) as a special verbatology form. The authors proceed from the general settings of narrative theory, and upgrade it with methodological achievements of verbatology, linguistics of text, genius and functional stylistics, - with the aim to specify the notions of discourse and text in the theoretical discussion. Considering various approaches to these concepts and definitions of the two concepts, as formulated and observed from various theoretical aspects, the authors have come to believe that a text and a discourse are actually higher rank structures in relation to the syntactic language forms, i.e. that the forms of suprasentential or, actually, genre organization of the verbal activities are on one side, while the forms of its written representation are on the other side. Here we have the concept of discourse in the foreground, and we have understood the text as a support, i.e. as our starting point in the discussion, in relation to which we define the discourse. Observed in such theoretical perspective - a discourse represents the linguistic base and the structural background of the text, including all important processes of preparation and creation of structural forms of the verbal activity as a whole.
\end{abstract}

Keywords: Discourse, Text, Sentence, Statement

\section{Introduction}

1. Eversince Zellig Harris has published his "Discourse Analysis", this topic has become very popular among linguists. As in the case of a text, there are diverse, often conflicting perceptions of a discourse in science as well. Harris understood "discourse" as "a class distribution sample" [1], i.e. a precise text, as opposed to the categorical concept of suprasentential structure (which would be the subject of text linguistics). It is obvions that the concept of discourse is inseparable from the concept of a text according to Harris, and therefore we will primarily observe the discourse relying upon perceptions of the text. However, before we proceed to discussion, we will recall some thoughts about a discourse. The authors gave their judgment on it in a joint book titled Verbatology: Linguistic Basis of the Science on World Verbalization [2]. In this study we are mainly relying on those findings.

2. Unlike "a text", the concept of "discourse" includes dynamic aspects, mainly directed to the production, as well as to the utilization level of the observation of forms. G. Genette [3] speaks "about a discourse, i.e. about the methods for building a story and, eventually, about its transfer to the recipient, and the impact on their cognitive apparatus and, further on, their internal state and external behavior". P. Abbott [4] mentions "a discourse, i.e. speaking in terms of literary theory - a narrative text". V. V. Dementjev [5] in his consideration points to "research and designing the discourse systematics". All in all, the diverse opinions can be reduced to the two constants. The first one indicates that the discourse is "a story building process", i.e. a dynamic concept opposed to the text as a static structure created in a "discursive" process. As fare as the second one is concerned, it is the text itself, i.e. the result of "a discourse".

3. In Simeon's dictionary, "discourse" is considered to be simply parsed, i.e. meaningfully organized, articulate speech [6]: "Discussion, speech, parsing; discursive - reasonable, thoughtful; derived by using reasonable parsing (opposite: intuitive)”. No matter 
how simplified and theoretically ungrounded they may seem, Simeon's interpretations must certainly be considered a classical basis serving as a starting point for contemporary considerations on the topic. The distinction between discursiveness and intuitiveness pertains to the very spiritual processes, opinions and emotions, but also vague anticipations. However, the linguistic organization depends not only on this, since a lyrical text is a highly organized material, as a rull, although it could not be reduced to discursive thinking without reserve, as defined by Simeon, i.e. ultimately logical.

4. Trask's dictionary contains different views [7]. In his opinion, a text is not simply a collection of spoken or written phrases or sentences, etc., but, as we have determined above for the text, it is organized in a certain manner, "A continuous piece of spoken or written language, especially one with a recognizable beginning and ending [...]. - For some linguists, a text is not different from a discourse. For the others, a text is, more or less, a product, the result of a discourse, that itself leads to the construction of a text. For still the others, a text is primarily defined by an identifiable purpose, and such interpretation leads to the classification into appropriate linguistic features. Yet others see a text as an abstraction, with a discourse being its realization. Finally, some linguists merely consider that a text is what is written, while a discourse is what is spoken".

5. Therefore, the relationship between a text and a discourse would actually be "genetic". Either a discourse exists before a text, probably as its actual or assumed basis, and a text is simply formed by its transformation into a written form, perhaps with certain adjustments. Or the text is older than the discourse and constitutes its basis, now certainly in the form of a yet unspoken virtual structure which is "verbalized" by verbal or written means. So, "think before you speak" really has some hidden theoretical sense, as the socalled "cognitive" linguists and psycholinguists discuss verbal strategies and, presumably, it is also necessary to discuss the strategy implemented in some constructive solutions preceding "articulation", i.e. Austin's "locution" [8]. This structural base or scheme must always go through the verbal innervation, even if it is not shaped aloud before it acquires its written form, if it is acquires at all in the text. There is also a so-called "unspoken speech", which is the product of Martinez's "first articulation" [9]. Therefore: on the basis of these considerations, it can be really concluded that a discourse is the basic form of expression and that a text is constructed on its foundation. However, this means that a verbally shaped expression is also a specific kind of text, as it follows innervation and articulation processes, which in that case represent preparation of both of them.

\section{A survey of Some Theoretical Views}

\subsection{Linguistic Interpretations of Discourse}

1. The explanations of the discourse in The Dictionary of Literary Terms are much more detailed, but in theoretical terms they do not exceed the framework that is already established by the mentioned formulations. The following views are presented there [10].

1) "Conversation, speech or discussion based on logical analysis and reasoning [.] The connotation of the great cultural and historical importance of a discourse is present in today's philosophy and sociology, which explain it as a discussion in the form of institutionalized expressions aiming at more precise presentation of a problem in exploring the creation and functioning, or communication between opposite opinions, assuming that, in principle, it is possible to achieve unanimity among the representatives of these opinions [.]".

2) In linguistics, according to the author of the dictionary article, a discourse is understood as a procedure through which individual parts (segments) are linked into "a coherent text" in a conceptualized manner, and this conceptualization, i.e. discursiveness is the subject of the study of psychology and psychoanalysis, as well as semiotics, while for contemporary narratology and rhetorics, which are primarily inspired by French poststructuralism, a discourse is the central concept, as opposed to the concept of "histoire". Unlike Russian Formalists, who in this case speak of "a fable" as a summarized totality of events in their interconnectedness, and of "a subject" as an artistically organized presentation of these events, mentioning also the word "system" to express the totality of the work, French post-structuralists do not only see this system as a totality in which each part performs its function, but also wish to understand the totality in the dynamics of its creation and conceptualization, as continuous interaction between the writer and the reader, as a discourse, where there is the main course, which the writer, however, can occasionally deviate from in a free play of numerous opportunities. G. Genette writes [3]: "A narrative is a story observed in relation to history, and a discourse is a story observed in relation to narration". This would mean that a discourse is actually only "storytelling", i.e. a textual structure building process.

2. Contemporary approaches mainly imply similar views concerning a discourse.

1) Trask's Dictionary [7] reads: "Any linked part of spoken or written language. A discourse can be produced by an individual speaker or writer, or by two or more people involved in a conversation or (less frequently) written communication [...] There are two fundamental terms in the study of discourse - 
cohesion and coherence. Cohesion implies the presence of direct linguistic links ensuring a recognizable structure, e.g. words such as "that", "this", "after", "therefore" and "but". Coherence is the meaningfulness level of a discourse based on value-based criteria for our knowledge about the world. For example, as an answer to the question "Who will drive us to the Christmas party?", the remark "Susan is on antibiotics" may seem irrelevant and non-compliant, but it gains sense if we know the connection between alcohol and Christmas parties, alcohol and driving, and alcohol and antibiotics". The anaphora of pronouns and the presupposition of expressions in general are the two important moments in achieving cohesion of speech and text and are sufficient for its understanding. However, this does not make these two forms of verbal emission different from each other. These and other significant material and organizational properties characterize a text, i.e. a discourse as a linguistically and meaningfully shaped entity.

2) Crystal's thesaurus [11] reads the following about discourse: "A term used to refer to a continuous stretch of (especially spoken) language larger than a sentence - but within this broad notion, several different applications may be found. At its most general, a discourse is a behavioral unit which has a pre-theoretical status in linguistics: it is a set of utterances which constitute any recognizable speech event; e.g. a conversation, a joke, a sermon, an interview. A classification of discourse functions, with particular reference to the type of subjectmatter, the situation, and the behavior of the speaker, is often carried out in sociolinguistic studies, e.g. distinguishing dialogues vs. monologues, or oratory, ritual, insults, narrative, and so on".

3) The Dictionary of Literary Terms [10] implies that a discourse is: "Based on logical consideration and reasoning. In the cognitive process, discursive thinking operates in accordance with logical principles, with rational step by step and analytical parsing. In literature, discursive essays imply primarily those forms in which the priority is given to the presentation of specific concepts and ideas (discussion, essay, study, etc.), as opposed to purely imaginative creations (drama, novel, lyrical and epic poetry, etc.). However, this distinction is not always ultimately sustainable having in mind that in certain periods poetry frequently had a highly discursive character as well, and that both a novel and drama sometimes contain purely discursive elements".

3. Discourse reviews are also contained in some specific linguistic and related works that we have come across, and we will briefly refer to them.

1) P. Vučković [12] judges a discourse from the standpoint of a psychologist and philosopher. In his opinion:
Speaking represents a specific process that is correspondent to understanding. In this process, the speaker has to plan the sentence/statement. For this purpose, he/she chooses terms that the listener needs to understand and words to express such terms. This is followed by the statement planning (part by part) and its realization [...] Speaking is essentially an instrumental act: people speak to produce a certain effect in listeners. Similar to understanding, speaking takes place in two stages: planning and realization of the statement. Speakers first plan what they want to say based on the manner in which they want to change the mental state (the sphere of knowledge) of their listeners, i.e. depending on the manner in which they want to influence the listeners. Speakers then proceed to the realization of that plan through the utterance of the linguistic units that are necessary for this purpose. In each stage of speaking, the speakers alternately plan and realize the statement, i.e. while they are uttering what they have previously planned, the speakers are simultaneously planning what they will say at the next moment. In other words, these two stages overlap in certain manner, and it is therefore not possible to precisely determine the line where the planning ends and the realization starts. The discourse planning is carried out as part of the uttered speaking stages. This process includes the speech act selection, the sentence planning (what is the subject of a sentence, what is old and what is new information, what is superior and what is subordinate), i.e. the planning of sentence constituents. The global plan is followed by the arrangement of words into phrases, and phrases into sentences, in the appropriate order. The final step includes the development and implementation of the articulation program [.].

Linguistic communication imposes the study of meaning within a triad: meaning (of the statement) - intention (of the speaker) - interpretation (of the interlocutor). If we add that communication / verbal interaction is always carried out within a context (coordinated in space and time), the context will become an unavoidable factor for explaining the meaning phenomenon [.]".

2) These reasonable considerations lead to the conclusion that, firstly, the verbalization process is not a mere utterance of voices, but is rather supported by a complex network of preparatory mental operations in the background, which is called "a verbal strategy" by some theorists. Vučkovič further expresses a view that the minimum component of a text/discourse is not a sentence, but - a statement. Regardless of what the author meant under this term, this seems as a warning that it is necessary to carefully consider the relationship between the statement and the sentence, as well as their relationship with the higher forms that they build.

4. Glovacki-Bernardi [13] has a specific view of a discourse. A discourse is superior to the concept of text: „A discourse can include one text only, as in the novel, or several texts, which occurs in a common conversation". This would mean that a discourse is 
actually, or at least in terms of a "common conversation" - supratextual organization of the linguistic expression.

\subsection{Textological Interpretations of Discourse}

1. Information regarding a text and a discourse is also contained in disciplines that are parallel to "text linguistics". Some of them have recently been established under the name "text analysis" and "discourse analysis", and some other less known methodological systems. Crystal [11] says the following:

In recent years, several linguists have attempted to discover linguistic regularities in discourses (discourse analysis), using grammatical, phonological and semantic criteria (e.g. cohesion, anaphora, inter-sentence connectivity). It is now plain that there exist important linguistic dependencies between sentences, but it is less clear how far these dependencies are sufficiently systematic to enable linguistic units higher than the sentence to be established. The methodology and theoretical orientation of discourse analysis (with its emphasis on well-formedness and rules governing the sequence of permissible units, in both spoken and written text) are often contrasted with those of conversation analysis. Some linguists adopt a broader, psycholinguistic perspective in studying discourse, which they view as a dynamic process of expression and comprehension governing the performance of people during linguistic interaction. Some adopt a sociolinguistic perspective, in which the purpose and function of the discourse are emphasized. This way the distance is provided from text linguistics, when this is seen as the formal account of the linguistic principles governing the structure of texts. But there is considerable overlap between the domains of discourse analysis and text linguistics, and any attempt at a principled distinction would be premature".

2. Therefore, a discourse can obviously be defined only in relation to a text, as a conceptual variant or a concept that is theoretically dependent on "a text". Namely, some theorists consider "discourse" as a synonym for "text". In the third opinion, these are also joined by "a statement". Others are of the opinion that the distinction between them lies in the fact that a text has "written", while a discourse has "verbal" form. This also implies other distinctions: a text is stable over time, while a discourse is not time-proof. A text is better arranged, while a discourse exhibits symptoms of spontaneity, etc. According to that, at least two broad areas of the language use would be covered by the discourse, with a minor and, for the totality of linguistic production, insignificant spillover into the text: these are the didactic sphere with the school teaching activity and the colloquial sphere.

3. According to the third idea, a significant factor for a discourse is that it is more primary than a text, when observed from diachronic and synchronic aspects. Namely, in the background of a written word, as we have already stated, there is always a spoken word - if not actually, than at least potentially.

4. However, there is also a specific perspective on the discourse not mentioned in our review, which is increasingly present in the cultural communication. For example, authors mention a "political discourse" [14], "Balkan discourse" [15], "theatrical discourse", "cryptographic discourse", "ideological discourse", "public discourse" - as well as "gender-labeled discourse of the policy in Serbia" [16], "discourse of the European Union", “journalistic discourse" [17], etc. Thus used, the term "discourse" actually means the totality of the linguistic production of a certain type or in a certain area of communication. It is then related to the so-called functional stylistics, but does not pertain to functional and stylistic forms, but, presumably, to the narrower, for the time being mainly arbitrarily separated corpora of the linguistic use, and the material offered by such use. We are of the opinion that the term "discourse" is justified in all of these meanings, where the most interesting for us is this latter idea of a discourse as a type of the linguistic use in any area of life and for any purpose. A similar view is expressed in Simeon's Dictionary of a text [6], except that the delimitation is socially, and not objectively conceived: "the entire sum [...] of verbal creations" of a given group. However, having in mind specific differences in understanding a discourse and a text, as well as the lack of exploration of the latter problem of "discursive linguistics", the understanding of these two terms in our considerations is very simplified: we consider them as synonyms, at least from the general aspect, and we thus mainly refer to a text(/discourse) and not to them separately.

\section{Conclusion}

The conclusion of our interpretation is that discourse can obviously be defined only in relation to the text, as a conceptual variant or theoretically depending on the term "text". It is only a question of the level at which the discourse as a whole is distinguished from the whole of speech activity, as a system of connected units or as a process of shaping the whole or the system. The question is also whether the discourse is a part of the text, i.e. a basis for its organization, or an overhead control term. And the question is from which perspective can you look at discourse when choosing the level of observation: whether it is an articulation or ideational phenomenon, i.e. whether it concerns a purely linguistic (superficial) structure, or is primarily understandable as the appearance of a thoughtful and (deep) communicative level. Perhaps it is best to take all the aforementioned foreign discursive activities and discourse to consider the totality of the communicative activity of the given environment and given circumstances - sometimes wider, sometimes even narrower. And this undoubtedly depends on the approach. If so, then the 
discourse verbalization process is recognizable among other things in that it functions in the interpersonal transmission of "messages".

\section{References}

[1] Z. Harris, "Discourse Analysis,"Language. Linguistic Society of America,vol. 28, No. 1, pp.1-30. Jan.-Mar., 1952.

[2] J. Jovanović Simić i R. Simić, Verbatologija (lingvističke osnove nauke o verbalizaciji sveta). Beograd: NDSJ i Jasen, 2015, pp. 14-29.

[3] G. Genette, Die Erzählung, 3. Aufl. Paderborn: Wilhelm Fink, 2009, pp.11-13.

[4] H. P. Abot, Uvod u teorijuproze. Beograd: Official Gazette, 2009 , pp.34.

[5] V. Dementjev, Teorija govornih žanrova, Moskva: Znak, 2010, pp.10.

[6] R. Simeon, Enciklopedijski rječnik lingvističkih naziva. Zagreb: Matica hrvatska, 1969, s.v. "diskurs".

[7] R. L. Tresk, Temeljni lingvistički pojmovi. Zagreb: Školska knjiga, 2005, s.v.“diskurs”.

[8] Dž. L. Ostin, Kako delovati rečima.Novi Sad: Književna zajednica Novog Sada, 1994, pp.22-27.
[9] A. Martine, Jezik i funkcija. Sarajevo: Svjetlost i Zavod za udžbenike, 1973, pp.59-61.

[10] RKT, Rečnik književnih termina, drugo, dopunjeno izdanje, ur. Dragiša Živković, Institut za književnost i umetnost u Beogradu. Beograd: Nolit, 1992. s.v."diskurs","diskurzivan".

[11] D. Kristal, Enciklopedijski rečnik moderne lingvistike. Beograd: Nolit, 1988, s.v. "diskurs".

[12] P. Vučković, Ogledi iz semantike i pragmatike. Beograd: Savremena administracija, 1995, pp.114-117.

[13] Zr. Glovacki-Bernardi, O tekstu. Zagreb: Školska knjiga, 2004, pp.27-44.

[14] R. Simić, Politički diskurs: inflacija reči u samoupravnom društvu. Jezička profilaksa. Zemun: MX Aktuel, 1996, pp.1029.

[15] B. Šijaković, Kritika balkanističkog diskursa. Prilog fenomenologiji drugosti Balkana. Nikšić: Jasen, 2000, pp.4763.

[16] N. Silaški, T. Đurović i B. Radić-Bojanić, Javni diskurs Srbije. Beograd: Centar za izdavačku delatnost Ekonomskog fakulteta, 2009, pp.31-37.

[17] J. Jovanović, Lingvistika i stilistika novinskog umeća. Jezičke i stilske osobine novinarstva. Beograd: Jasen, 2010, pp.7-30. 